\title{
PENGOLAHAN MOTIF TERINSPIRASI DARI KAIN BATIK GENDONGAN LIONG UNTUK PENGEMBANGAN PRODUK GENDONGAN MEI TAI
}

Agtha Juliani Purnama Dewi, Morinta Rosandini

(Email : agthamilkajuliani@gmail.com)

Program Studi Kriya

Fakultas Industri Kreatif

Universitas Telkom

Jl. Telekomunikasi No.1, Terusan Buah Batu, Bandung, Indonesia

\begin{abstract}
ABSTRAK
Kain batik gendongan liong mengalami penurunan minat karena dianggap kuno dan menyebabkan rasa pegal atau sakit pada bahu saat digunakan. Orang tua zaman sekarang lebih memilih menggunakan gendongan anak modern seperti mei tai yang penggunaannya bertopang pada dua bahu sehingga mengurangi rasa pegal atau sakit pada bahu. Namun di Indonesia saat ini produk gendongan mei tai masih menggunakan motif-motif umum seperti kartun atau bidang geometris dan belum mengandung unsur budaya, sehingga perlu adanya pengolahan aplikasi motif baru pada produk gendongan mei tai agar menambah nilai estetika sekaligus mengenalkan bentuk motif tradisional batik liong. Metode penelitian yang digunakan dalam penelitian ini adalah metode penelitian kualitatif dan kuantitatif dengan pengumpulan data dengan melakukan analisis visual terhadap kain batik gendongan liong, studi pustaka, observasi produk mei tai, wawancara bersama Certified Babywearing Consultant, dan melakukan eksperimen dengan mengolah motif pada kain batik gendongan liong. Hasil akhir dari penelitian ini adalah inovasi visual motif yang terinspirasi dari kain batik gendongan liong dengan komposisi dan bentuk yang lebih modern, serta terciptanya produk gendongan mei tai yang menerapkan rancangan pengolahan motif yang terinspirasi dari kain batik liong yang lebih modern.
\end{abstract}

Kata Kunci: Batik; Gendongan liong; Mei tai; Modern; Motif

\section{ABSTRACT}

The liong batik cloth has decreased interest because it is considered old-fashioned and causes soreness or pain in the shoulders when used. Parents today prefer to use modern children's slings such as mei tai, which supports both shoulders to minimize shoulder soreness or pain. However, mei tai products nowadays still using general motifs such as cartoons or geometric fields and do not contain cultural elements. It is necessary to improve new motifs in mei tai products by adding some aesthetic value while introducing traditional liong batik motifs. The research method used in this research is qualitative and quantitative research methods by collecting data by conducting visual analysis of liong batik cloth, literature study, observation of mei tai products, interviews with Certified Babywearing Consultants, and conducting experiments by processing motifs on liong batik cloth cloth. This research's final result is a visual innovation of motifs inspired by liong batik cloth with more modern composition and shape and the creation of mei tai sling products that apply motif processing designs inspired by the more modern liong batik cloth.

Keywords: batik; liong sling; mei tai; modern; motif 


\section{PENDAHULUAN}

Salah satu kekayaan budaya yang dimiliki oleh Indonesia adalah batik. Jenis batik yang terkenal adalah batik pesisir, dimana batik ini muncul karena berada di daerah pesisiran utara Pulau Jawa seperti Cirebon, Indramayu, Lasem, dan lain sebagainya. Menurut (Wulandari, 2011), batik pesisir memiliki ciri khas, yaitu motif, ragam hias dan warnanya lebih beragam, serta dipengaruhi oleh kebudayaan asing, karena daerah pesisiran utara Pulau Jawa merupakan jalur perdagangan pada zaman dahulu.

Salah satu produk warisan kebudayaan Indonesia yang banyak menggunakan batik pesisir adalah kain batik gendongan. Kain batik gendongan biasa digunakan oleh perempuanperempuan Indonesia zaman dahulu untuk membantu dalam pekerjaan rumah tangga seperti menggendong bakul atau barang, dan yang paling umum adalah untuk menggendong bayi. Menurut (Ishwara, 2011) ada batik yang khusus dibuat untuk gendongan bayi yang memiliki ukuran standar sekitar $300 \times 80 \mathrm{~cm}$ atau $300 \times 100 \mathrm{~cm}$. Di Tuban kain batik gendongan disebut sayut yang memiliki arti "membalut", "melingkar", "bersatu membela sesama", hal itu diungkapkan oleh Heringa (2011) dalam buku batik pesisir Pusaka Indonesia.

Kain batik gendongan sarat akan makna dan filosofi didalamnya, salah satunya kain batik gendongan liong. Kain batik gendongan memiliki makna yang dalam pada tiap motifnya, dimana terdapat motif naga Cina, qilin, dan bunga anyelir. Selanjutnya diungkapkan bahwa motif liong atau naga Cina dipercaya sebagai pelindung, penolak bala, pemberi rezeki, dan kesuburan bagi kepercayaraan orang-orang Cina (Ishwara, 2011). Berlaku juga untuk motif qilin yang merupakan lambang dari kemurnian kebenaran, keadilan, kemakmuran, kedamaian dan motif bunga anyelir yang merupakan lambang dari pernikahan, kesuburan, serta rezeki yang melimpah. Namun seiring berjalannya waktu, kain batik gendongan dianggap kuno dan meskipun masih diproduksi namun kain batik gendongan liong yang diproduksi saat ini memiliki perbedaan yang dari gendongan batik liong yang diproduksi zaman dahulu. Secara struktur kain gendongan, gendongan batik liong saat ini yang diproduksi tidak memiliki bagian jumbai atau rumbai. 
Berdasarkan wawancara dengan Ibu Afifah Mu'minah (2019) yang berprofesi sebagai Certified Babywearing Consultant, diketahui bahwa ibu-ibu yang masih menggunakan kain batik gendongan sesuai dengan fungsinya untuk menggendong anak, sangatlah sedikit. Menurut ibu Afifah Mu'minah, alasan mengapa hal itu terjadi karena kain batik gendongan terkesan kuno dan minimnya pengetahuan masyarakat mengenai filosofi yang terkandung didalamnya. Selain itu dalam pemakaiannya, kain batik gendongan ditopang pada satu bahu, sehingga dapat menyebabkan rasa pegal atau sakit pada bahu, hal itulah yang merupakan penyebab ibu-ibu zaman sekarang lebih memilih gendongan modern yang dalam penggunaannya bertopang pada dua bahu.

Salah satu jenis produk gendongan bayi atau anak modern adalah mei tai, yang merupakan sebutan untuk produk gendongan bayi yang berasal dari Asia Timur, khususnya negara China dan sekitarnya. Menurut (Ismawati, 2019) yang tertulis dalam artikelnya, mei tai memiliki 4 tali pengikat utama dan dalam pemakaiannya, mei tai ditopang pada kedua bahu, sehingga aman untuk digunakan dan nyaman bagi ibu dan bayi. Di Indonesia mulai banyak pengguna gendongan jenis mei tai dan ada beberapa brand lokal yang memproduksi gendongan jenis mei tai seperti NaNa dan The Nest. Umumnya motif yang digunakan pada produk gendongan mei tai masih menggunakan motif kartun atau animasi hewan, namun kedua brand lokal ini telah menerapkan motif dengan teknik rintang warna yaitu ikat celup (tye dye) ke dalam beberapa produk mereka dengan tujuan mengangkat unsur budaya Indonesia. Meskipun begitu, sejauh ini belum ada brand yang menerapkan motif batik pada produk gendongan mei tai.

Dari fakta dan permasalahan di atas, muncul adanya potensi pengembangan pada gendongan jenis mei tai dengan menerapkan pengolahan estetik yang modern yang terinspirasi dari motif kain batik gendongan liong yang sarat akan makna dan filosofi pada produk, dengan teknik digital printing untuk menambah unsur budaya, serta memperhatikan kenyamanan pemakai, sehingga produk gendongan modern jenis mei tai memiliki motif alternatif yang mengandung unsur budaya.

\section{Motif}


Berdasarkan (Kight, 2011) pada bukunya mengungkapkan bahwa motif adalah unit terkecil atau paling mendasar dari sebuah pola desain. Motif yang berulang sangat diperlukan untuk menciptakan sebuah pola atau pattern, dan pola yang mengalami pengulangan akan menciptakan sebuah desain.

\section{Orientasi Motif}

Menurut (Kight, 2011) ada 2 arah cetak (directionality) dan penjelasannya sebagai berikut :

1. Cetakan Langsung (Directionality Prints).

Cetakan langsung adalah cetakan motif pada kain dengan mengikuti panjang arah kain.

2. Cetakan Tidak Langsung (Nondirectionality Prints).

Cetakan tidak langsung biasa digunakan pada produksi kain kebutuhan apparel, itu dikarenakan potongan-potongan pola dapat dipotong ke segala arah.

\section{Teknik Pengolahan Motif}

Berdasarkan penelitian (Kudiya, 2019) memaparkan pengertian stilasi dimana menurutnya stilasi merupakan suatu cara atau teknik penyederhanaan atau penambahan pada penampilan suatu benda atau objek secara visual baik penggayaan ataupun bentuknya, namun masih memperlihatkan bentuk ciri khasnya atau rupa aslinya.

\section{Teknik Pengulangan Motif}

Menurut (Kight, 2011) ada tiga jenis teknik pengulangan motif, antara lain :

1. Pengulangan Motif Persegi (Square Repeat)

Teknik pengulangan motif ini adalah yang paling sederhana karena cukup mengulang motif dengan menggeser 1 blok atau satu langkah.

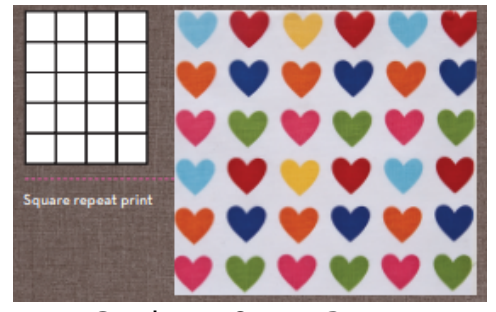

Gambar 1. Square Repeat Sumber: Kight, 2011

2. Pengulangan Motif Setengah Langkah (Half Drop Repeat) 
Teknik pengulangan motif ini cukup mengulang motif dengan menggeser $1 / 2$ blok atau setengah langkah ke bawah atau ke atas.

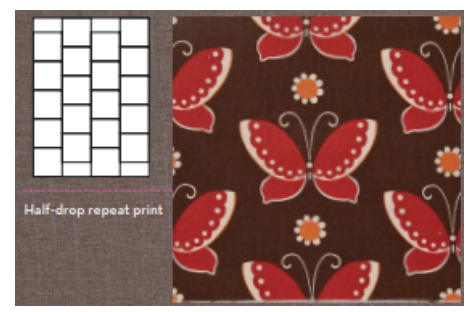

Gambar 2. Half Drop Repeat Sumber: Kight, 2011

\section{Pengulangan Motif Batu Bata (Brick Repeat)}

Teknik pengulangan motif ini cukup mengulang motif dengan menggeser $1 / 2$ blok atau setengah langkah ke kanan atau ke kiri seperti menyusun batu bata.

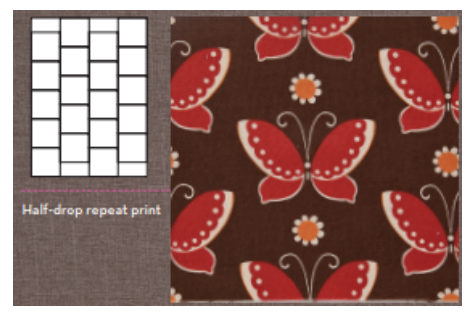

Gambar 3. Brick Repeat

Sumber: Kight, 2011

\section{Peran Motif Pada Produk Fashion}

Pada industri fashion, unsur desain menjadi bagian penting dari persentase penilaian konsumen. Value proposition yang dimana salah satunya adalah penggunaan motif tekstil pada produk fashion dapat menjawab kendala serta mengatasi persaingan bisnis serta dapat meningkatkan penjualan produk fesyen dan memenuhi kebutuhan konsumen akan sesuatu yang inovatif (Tjandrawibawa, 2018), oleh karena itu penggunaan motif sangatlah penting.

\section{Batik Pesisir}

Menurut (Wulandari, 2011), adanya istilah "pesisir" karena keberadaan wilayah yang terletak di sepanjang tepi utara pulau Jawa, sehingga batik pesisir sendiri dapat diartikan sebagai batik yang berasal dari daerah pesisiran utara pulau Jawa seperti Lasem, Indramayu, Pekalongan, dan 
masih banyak lagi. Batik pesisir terkenal akan kaya corak, simbol-simbol, dan juga warnawarnanya, hal itu dikarenakan batik pesisir dipengaruhi oleh budaya asing.

\section{Kain Batik Gendongan}

Kain batik sangat erat hubungannya dengan manusia di masa lampau, itu dikarenakan dari manusia lahir, masa anak-anak, remaja, dewasa, tua, hingga tutup usia kain batik selalu digunakan. Perkataan seorang antropolog asal Belanda Rens Heringa yang mengatakan bahwa di Tuban kain batik gendongan disebut dengan Sayut yang berarti "membalut" atau "melingkar", selain itu ukuran kain batik gendongan sendiri adalah $300 \times 80 \mathrm{~cm}$ atau $300 \times 100 \mathrm{~cm}$, bila ada kelebihan panjang dan lebar pasti tidak lebih dari ukuran tersebut (Ishwara, 2011).

Dalam bukuberjudul Beloved Burden, (Hout, 2015) dielaskan bahwa kain gendongan memiliki bagian-bagian, antara lain :

1. Pelemahan. Pelemahan memiliki arti tanah untuk penanaman atau bangunan. Bagian ini berada ditengah kain batik gendongan yang berisi banyak motif. Bagian ini dikelilingi oleh pinggiran atau tepian.

2. Pinggiran. Pinggiran berisi motif yang mengelilingi kain dan garis polos tanpa ada hiasan.

3. Bathuk. Merupakan bagian garis yang bergelombang. Bagian ini menggambarkan vulva atau area masuk kemaluan perempuan.

4. Kemadha atau Pengadha. Merupakan bagian garis vertikal, yang memiliki arti ujung jarum dan bisa disebut juga sebagai rumbai atau jumbai imitasi. Bagian ini yang menjadi ciri khas kain batik gendongan yang membedakannya dari kain panjang lainnya.

5. Jumbai atau Rumbai. Merupakan bagian ujung dari kain batik gendongan yang menggambarkan rambut pada area kemaluan perempuan. Pada zaman sekarang tidak semua kain batik gendongan memiliki bagian ini. 


\section{Kain Batik Gendongan Liong}

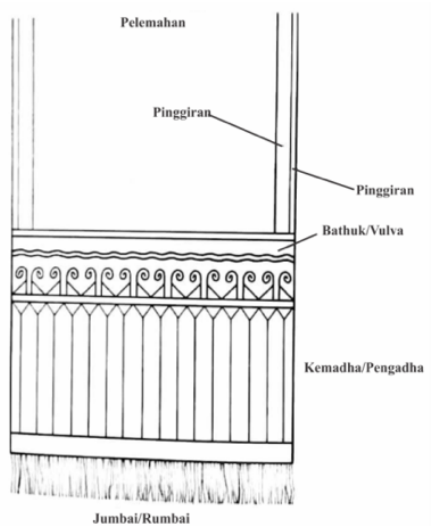

Gambar 4. Struktur Kain Batik Gendongan Sumber: Hout, 2015

Salah satu kain batik gendongan yang terkenal dan umum digunakan adalah kain batik gendongan liong. Ada beberapa motif yang terdapat pada kain batik gendongan liong, yaitu :

1. Naga atau liong. Naga merupakan makhluk sakti kepercayaan masyarakat Cina, konon naga dipercaya sebagai pelindung, penolak bala, pemberi rezeki, dan kesuburan (Ishwara, 2011)

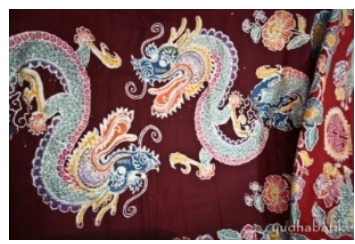

Gambar 5. Motif liong

Sumber: i.pinimg.com, 2019

2. Qilin. Qilin juga merupakan makhluk sakti kepercayaan masyarakat Cina. Menurut pemaparan (Ishwara, 2011), konon qilin dilambangkan sebagai isyarat kabar baik, kemurnian, kebenaran, keadilan, kemakmuran, kedamaian, dan kesuburan.

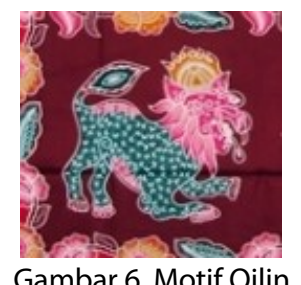

Sumber: kainbatikbatik.blogspot.com, 2019

3. Bunga anyelir atau Carnation, (Ishwara, 2011) memaparkan bahwa bunga anyelir dipercaya oleh masyarakat Cina sebagai lambang dari pernikahan, kesuburan, dan rezeki yang melimpah. 


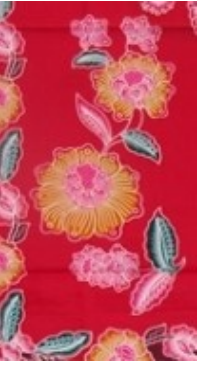

Gambar 7. Motif Bunga Anyelir

Sumber: kainbatikbatik.blogspot.com, 2019

4. Shuang Xi. Motif tulisan Cina yang memiliki arti kebahagiaan ganda.

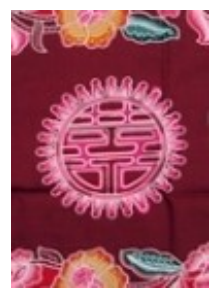

Gambar 8. Motif Shuang Xi

Sumber: kainbatikbatik.blogspot.com, 2019

5. Yin dan Yang. Yin memiliki arti tempat teduh atau gelap sedangkan Yang memiliki arti tempat yang terang. Secara filosofi, Yin dan Yang adalah kekuatan yang bertolak belakang atau berlawanan, namun saling melengkapi.

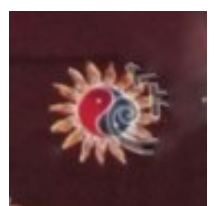

Gambar 9. Motif Yin dan Yang

Sumber: kainbatikbatik.blogspot.com, 2019

\section{Gendongan Anak}

Menggendong adalah sebuah tradisi budaya yang sudah ada sejak zaman dahulu kala. Sebuah budaya dimana anggota keluarga terlibat dalam tumbuh kembang anak, khusunya dalam memberi rasa aman dan nyaman pada anak yang baru saja lahir. Menggendong tidak hanya dilakukan oleh ibu namun juga seluruh anggota keluarga memiliki peranan didalamnya. Karena budaya menggendong inilah, muncul adanya alat menggendong yang disebut gendongan 
anak. (Holmes, 2019) menyebutkan dalam artikelnya yang berjudul Baby Carrier bahwa gendongan anak bertujuan untuk menjaga bayi berada dekat dengan anggota keluarga agar tecipta rasa aman dan nyaman sambil mereka melakukan rutinitas

\section{Gendongan Mei Tai}

Dalam artikel berjudul Vintage Mei tai Part 1 yang di publish pada website hipababy.com (Vintage Mei tai / Meh Dai Part 1., 2018), dijelaskan tentang arti nama mei tai. Mei tai yang dalam goresan tulisan Cina 背带 memiliki arti gendongan bayi. Sesuai namanya mei tai merpakan gendongan yang berasal dari Asia timur, seperti negara Cina dan sekitarnya. Mei tai merupakan gendongan bayi berbentuk persegi atau persegi panjang dengan 4 panel tali, dimana 2 panel tali berada di atas dan 2 panel tali lainnya berada di pinggang. Panjang dari pada tali panel adalah $110 \mathrm{~cm}$, itu dikarenakan panel tali di pakai dengan cara dililitkan dan diikat. Saat ini Mei tai telah dilengkapi fitur tambahan seperti, penahan kepala, tudung tidur, saku, dan sebagainya yang dibutuhkan para ibu pada umumnya, berfungsi untuk menambah kenyaman anak saat digendong. Gendongan Mei tai memiliki 5 bagian dasar, (McCarthy, 2007) menuliskan dalam website carrymeaway.com ada 5 bagian dasar pada gendongan mei tai, antara lain :

1. Bagian Tubuh, yang merupakan kain berbentuk persegi panajang yang merupakan tempat duduk bayi dan penyangga kaki serta punggung bayi.

2. Ikat Pinggang, merupakan pita yang pembatas antara kain bagian tubuh dan pita pinggang.

3. Tali bahu, merupakan pita panjang yang berfungsi mengikat gendongan pada bahu ibu dan dililitkan pada tubuh bayi dan diakhiri dengan simpul tali.

4. Tali pinggang, merupakan pita panjang yang berfungsi mengikat gendongan pada bagian pinggang ibu dan dililitkan pada tubuh bayi serta diakhiri dengan simpul tali.

5. Tudung, tidak semua produk gendongan mei tai memiliki tudung kepala, namun rata-rata gendongan ini diproduksi dengan memiliki tudung, dengan fungsi sebagai penopang kepala bayi ataupun penutup kepala bayi. 


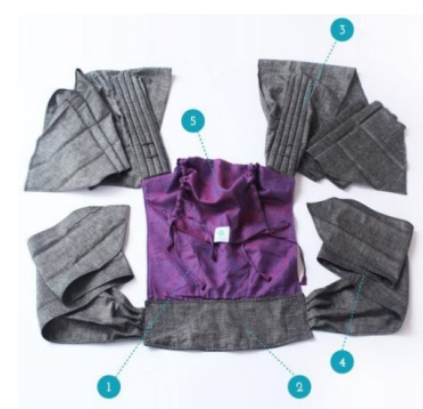

Gambar 10. Gendongan Mei tai

Sumber : Carrymeaway.com, 2019

\section{METODE PENELITIAN}

Metode penelitian yang digunakan dalam penelitian ini adalah metode kualitatif yang bersifat analisis mendalam yang terstruktur dan deskriptif, serta menggunakan metode kuantitatif yang bersifat objektif dalam pengumpulan data dan penafsiran data yang terkait dengan penelitian.

Berikut teknik pengumpulan data yang digunakan dalam penelitian, antara lain :

1. Studi Pustaka. Metode pengumpulan data dengan mempelajari beberapa sumber tulisan seperti buku-buku, karya ilmiah, tugas akhir, dan lain-lain.

2. Observasi. Metode pengumpulan data dilakukan dengan observasi visual kain batik gendongan liong, serta observasi terhadap beberapa brand gendongan jenis Mei tai melalui website, instagram dan beberapa e-commerce.

3. Wawancara. Metode pengumpulan data dilakukan dengan percakapan terhadap ibu Afifah Mu'minah selaku Certified Babywearing Consultant.

4. Eksperimen. Metode pengumpulan data dilakukan dengan eksperimen atau percobaan pengolahan motif kain batik gendongan liong dimana ada eksperimen tahap awal, lanjutan dan hasil akhir.

\section{PEMBAHASAN}

\section{Konsep Perancangan}

Konsep perancangan riset inovasi ini adalah pengolahan motif pada kain batik gendongan liong menjadi lebih modern, sehingga dapat menjadi desain alternatif untuk pengembangan produk gendongan mei tai. Adapun pertimbangan-pertimbangan yang dilakukan dalam proses pengerjaan dan produksi sebagai berikut : 
1. Material. Material yang akan digunakan adalah kain yang berbahan $100 \%$ serat alam, dimana bahan tersebut aman digunakan bagi bayi atau anak kecil yang memiliki kulit sensitif bila dibandingkan dengan kulit orang dewasa sesuai dengan saran ibu Afifah Mu'minah selaku Certified Babywearing Consultant. Kain 100\% serat alam termasuk bahan yang kuat sehingga aman bila digunakan untuk mengangkat beban khusunya berat badan bayi atau anak kecil.

2. Warna. Warna yang digunakan adalah warna-warna solid yang biasa digunakan pada kain batik gendongan liong yang khas dengan warna-warna batik pesisiran khususnya batik pecinan yang merupakan batik dengan pengaruh kebudayaan Cina. Warna-warna tersebut juga yang menjadi acuan untuk imageboard.

Pengolahan motif yang digunakan peluang merunut pada penggayaan stilasi motif pada kain batik gendongan liong yang dimana menggunakan penggayaan RWD (Ruang, Waktu, dan Datar).

\section{Analisis Penggayaan Motif Batik Gendongan Liong}

Analisis visual ini dilakukan pada kain batik gendongan liong milik pribadi yang dimiliki sejak tahun 1996.

Tabel 1. Analisis Visual Motif Batik Gendongan liong

\begin{tabular}{|c|c|}
\hline Gambar & Keterangan \\
\hline & $\begin{array}{l}\text { Penggayaan } \\
\text { Serupa dengan beberapa kain batik gendongan klasik, } \\
\text { salah satunya adalah kain Batik Gendongan Lasem } \\
\text { menurut (Rosandini \& Kireina, 2020) batik tersebut } \\
\text { memiliki karaktertistik bahasa rupa primitif dimana } \\
\text { didalamnya mengandung cerita yang tidak bebatas } \\
\text { ruang, tempat, dan waktu. Ada kisah yang ingin } \\
\text { diceritakan oleh para pengrajin motif batik dahulu, juga } \\
\text { sebagai bentuk komunikasi untuk memberikan } \\
\text { pengharapan yang baik bagi para pemakainya, khususnya } \\
\text { bagi ibu dan anak yang menggunakan }\end{array}$ \\
\hline
\end{tabular}




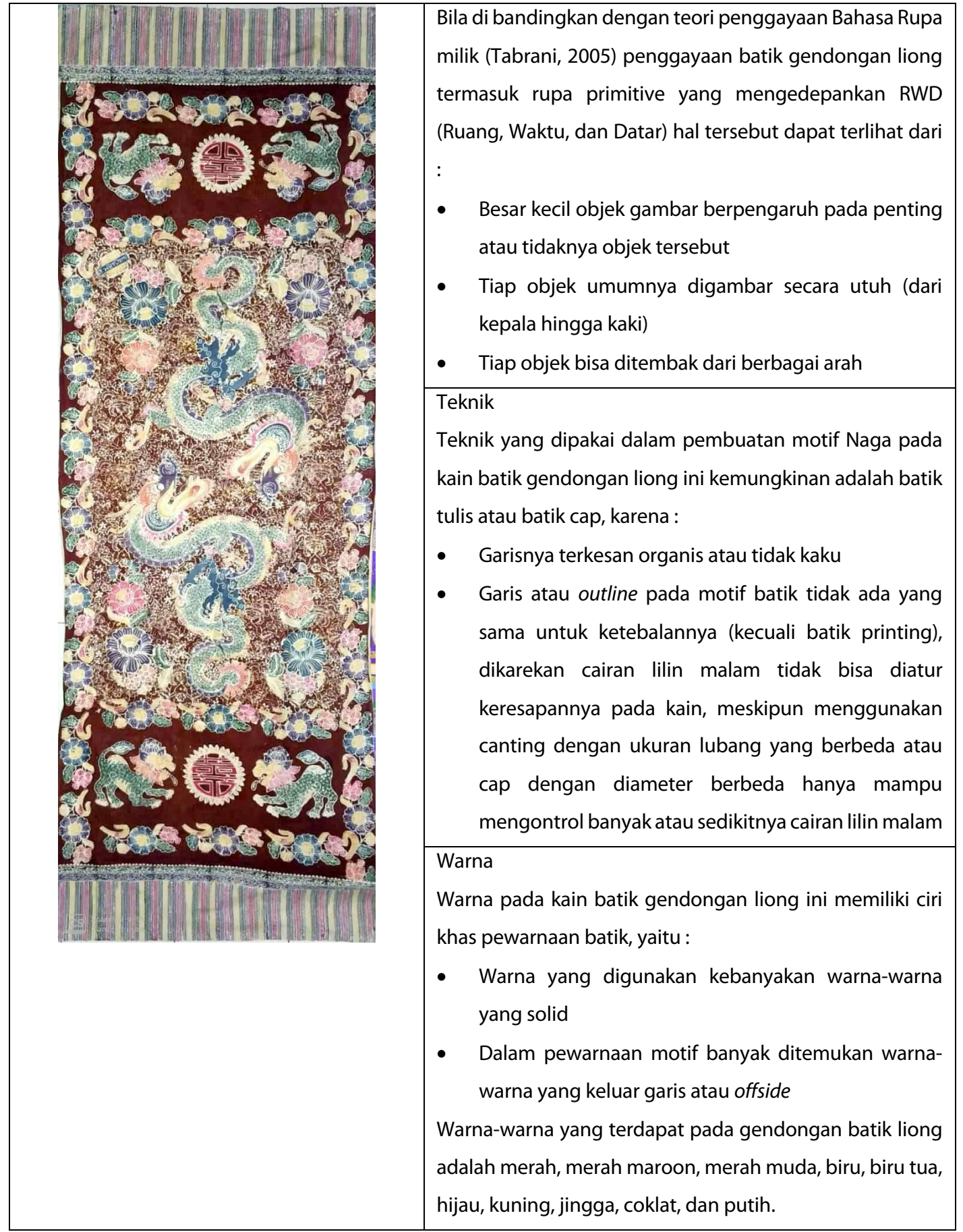

\section{Konsep Pengembangan Desain}

Gagasan yang dirancang bagi para orang tua khusunya bagi para ibu yang memiliki anak. Dengan kehidupan yang sederhana dan cinta alam. Para orang tua yang memiliki ketertarikan 
akan kebudayaan, serta mengutamakan kenyamanan dan keamanan barang-barang yang digunakan khususnya bagi sang anak. Warna yang diambil adalah warna-warna solid yang terdapat pada kain batik gendongan liong sehingga tetap memberikan kesan batik pesisir.

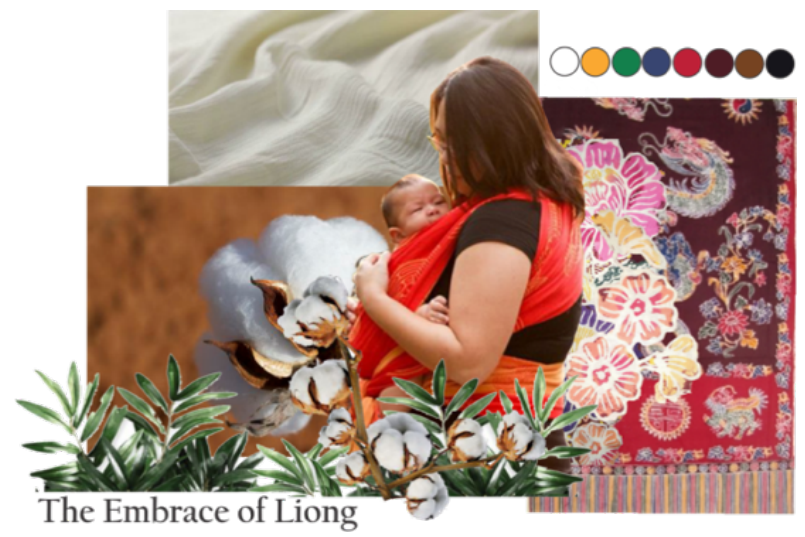

\section{Eksplorasi Motif}

Gambar 11. Imageboard

Sumber : Penulis, 2019

Eksplorasi awal yang dilakukan adalah membuat stilasi motif yang terinspirasi dari motif-motif kain batik gendongan dengan pertimbangan-pertimbangan unsur dan prinsip rupa, yang bertujuan terciptanya motif dengan bentuk yang lebih modern dikarenakan belum adanya pengembangan motif terhadap kain batik gendongan liong. Stilasi motif dilakukan dengan membuat sketsa gambar motif yang terinspirasi dari motif kain batik gendongan liong yang kemudian disederhanakan atau ditambahkan dengan beberapa detail dengan pertimbanganpertimbangan unsur dan prinsip rupa, namun masih terlihat wujud atau rupa asli dari motif kain batik gendongan liong tersebut.

Tabel 1. Stilasi Motif

\begin{tabular}{|c|c|c|}
\hline No. & Inspirasi & Stilasi \\
\hline
\end{tabular}


Serat Rupa Journal of Design, July 2021, Vol.5, No.2: 230 - 253

E-ISSN: 2477-586X, ISSN: 2338-3348 | https://doi.org/srjdv5i2.2798. | Received: 03-08-2020 Accepted: 19-07-2021 Agtha Juliani Purnama Dewi, Morinta Rosandini

Pengolahan Motif Terinspirasi Dari Kain Batik Gendongan Liong Untuk Pengembangan Produk Gendongan mei tai

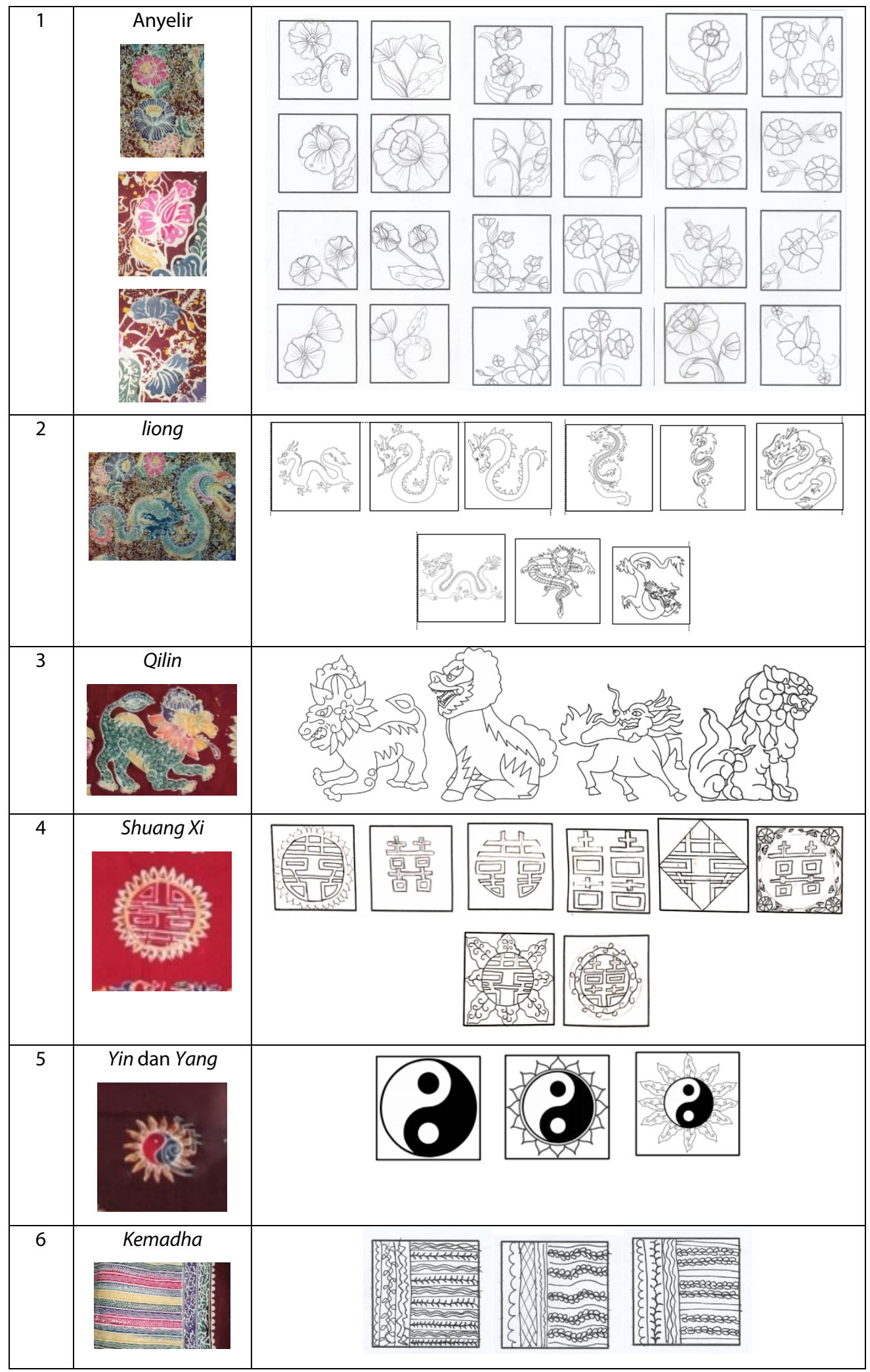

Sumber: Penulis, 2019 


\section{Eksplorasi Warna}

Setelah melakukan eksplorasi awal dengan melakukan stilasi motif dari motif-motif kain batik gendongan, dengan pertimbangan-pertimbangan unsur dan prinsip rupa, tahap selanjutnya yaitu memberi warna pada stilasi yang telah dilakukan. Pewarnaan yang dilakukan atas pertimbangan warna asli dari kain batik gendongan liong.

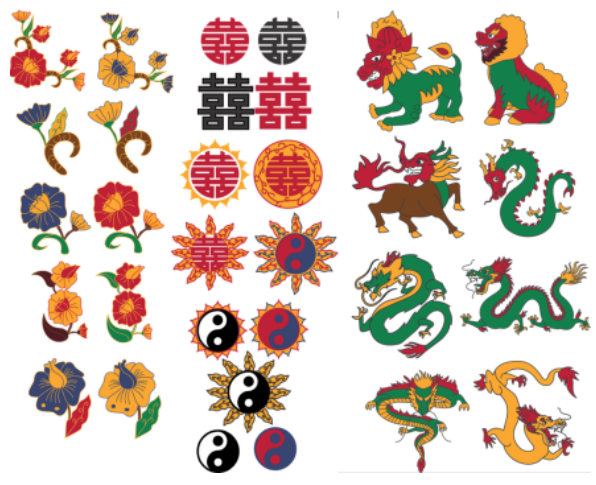

Gambar 12. Eksplorasi Warna Sumber : Penulis, 2019

\section{Eksplorasi Teknik dan Warna}

Pada tahap ini penulis melakukan eksplorasi lanjutan dengan menerapkan teknik dan warna yang telah dianalisis sebelumnya dengan tujuan menghasilkan garis menyerupai motif yang dibatik menggunakan malam atau lilin serta pewarnaan yang terkesan offside.
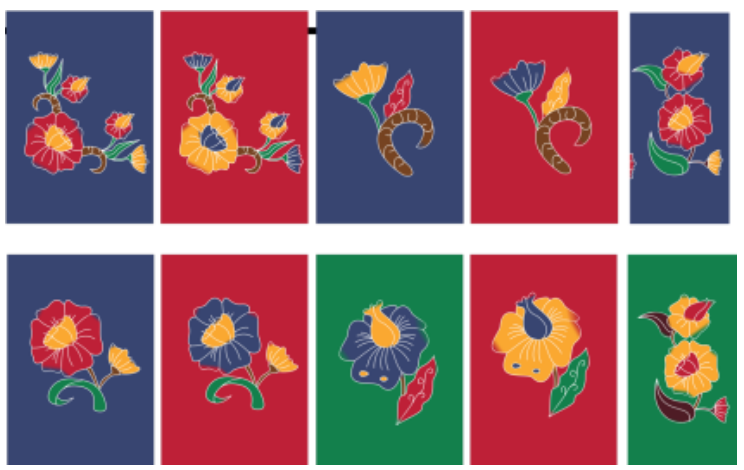

Gambar 13. Eksplorasi Teknik dan Warna

Sumber : Penulis, 2020

\section{Komposisi dan Warna}


Penulis melakukan eksplorasi lanjutan dengan melakukan pengembangan komposisi awal dengan pertimbangan-pertimbangan unsur dan prinsip rupa serta teknik repetisi dan orientasi motif, serta menerapkan teknik garis dan pewarnaan offside khas batik.

Tabel 2. Komposisi dan Warna

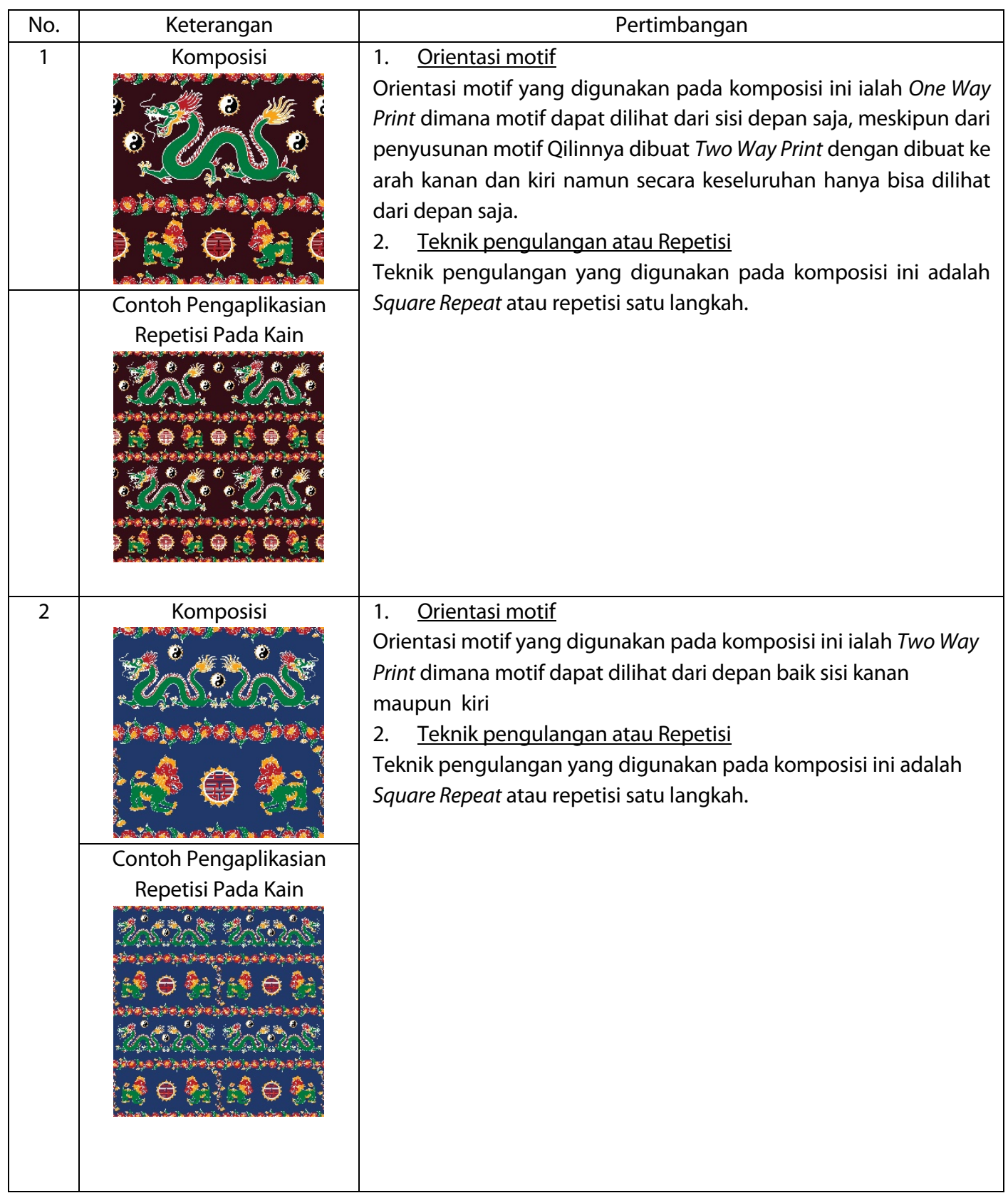




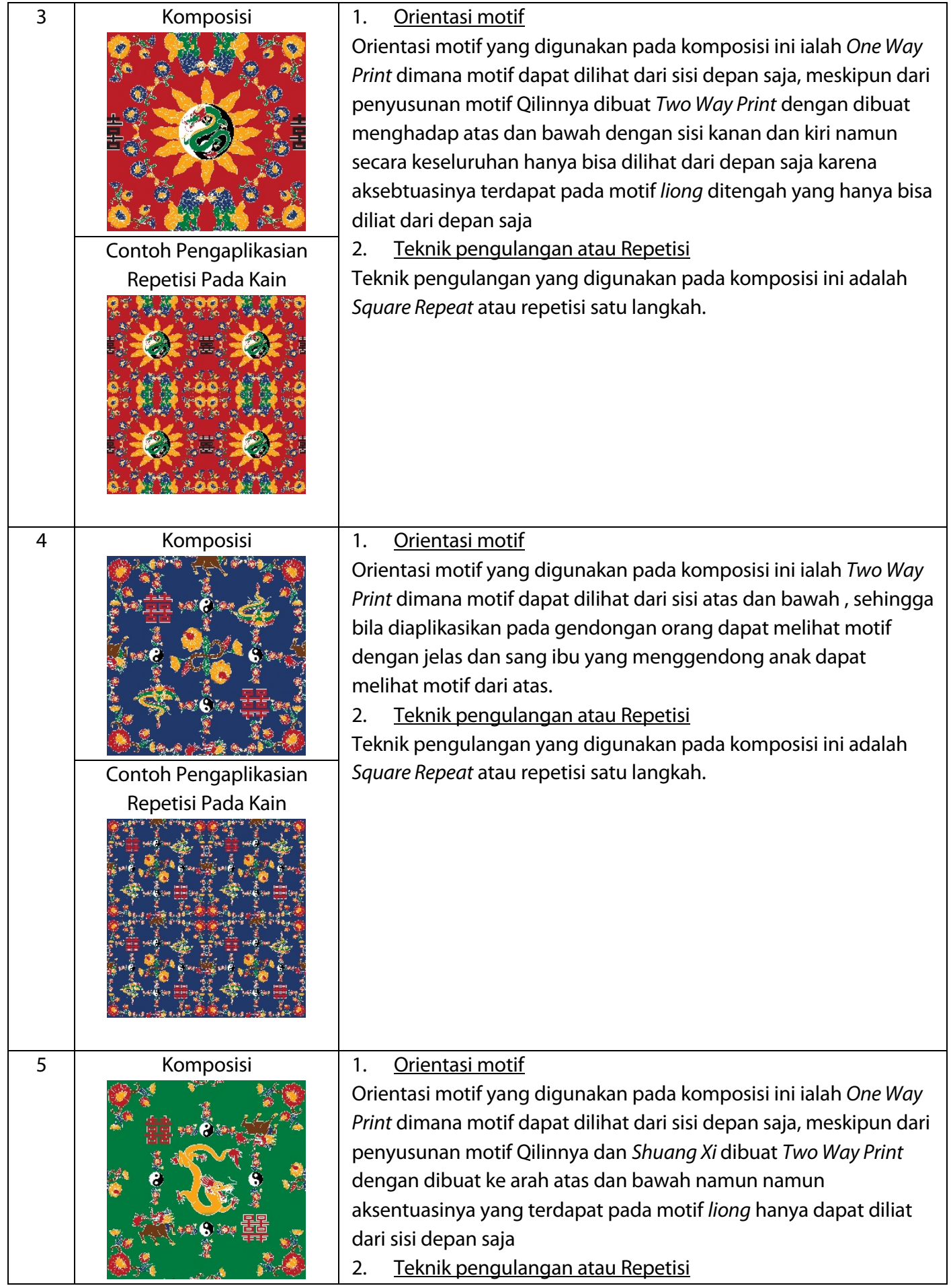




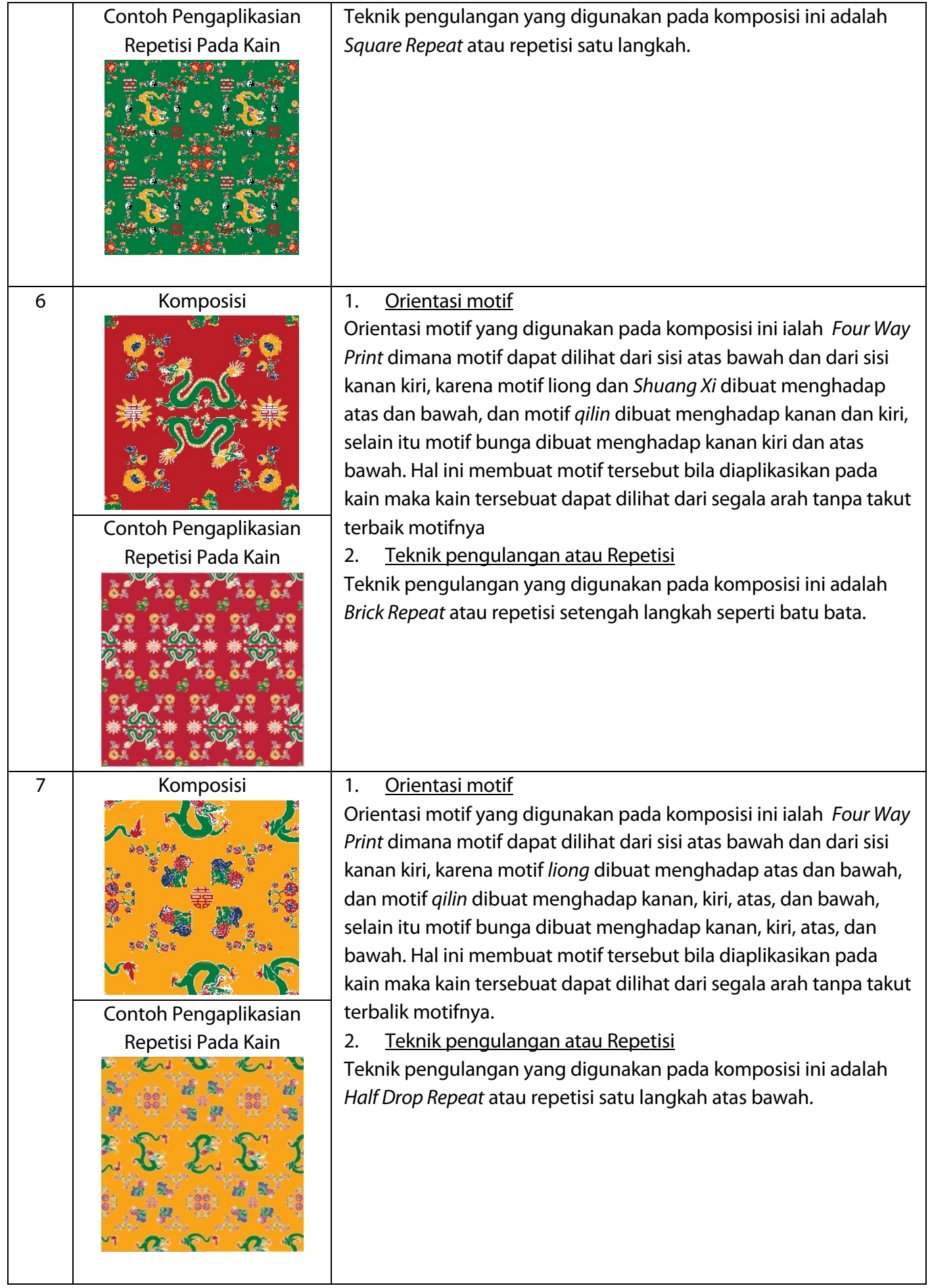




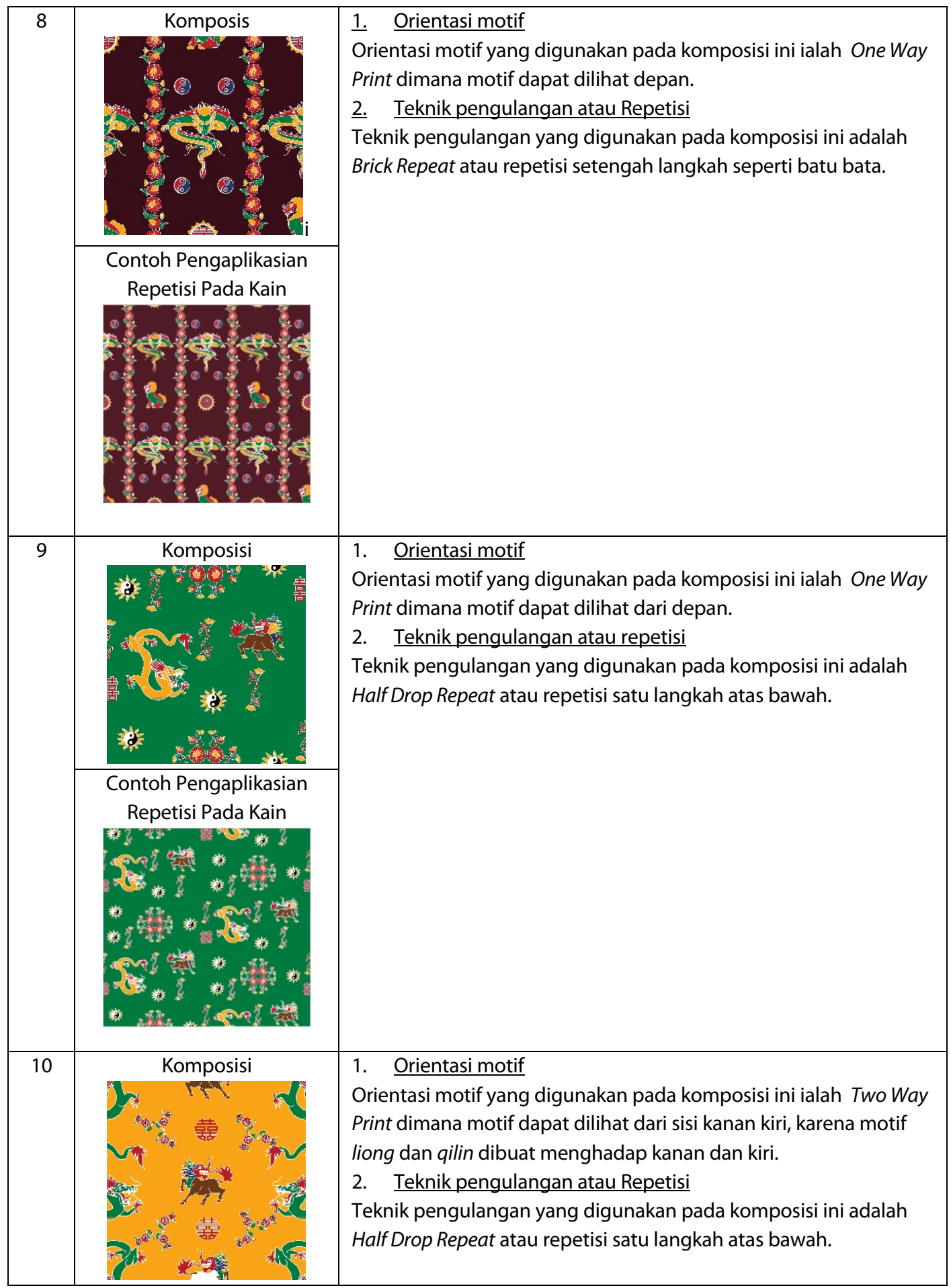




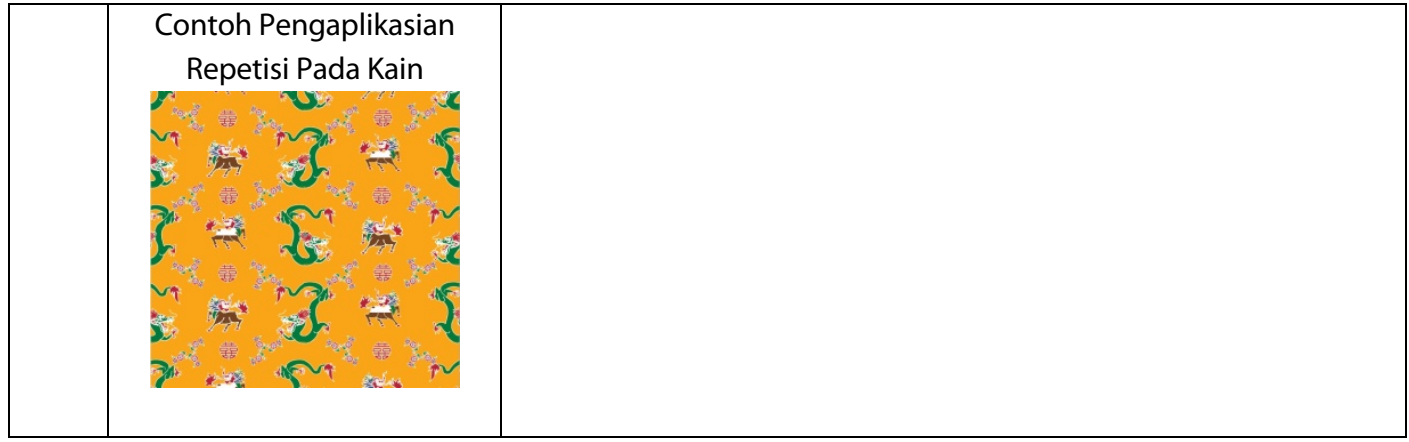

Sumber: Penulis, 2020

\section{Aplikasi Pada produk}

Aplikasi motif yang sudah dirancang dilakukan dengan melakukan uji cetak digital dengan menggunakan jenis kain baby canvas yang memiliki karakter kain yang sama dengan euca canvas (bahan yang cocok dengan kulit bayi) baik dari segi tekstur maupun ketebalannya. Uji cetak dilakukan dua kali dari vendor yang berbeda, dan hasil terbaik didapatkan dari uji kedua dengan hasil akhir cetak yang warna yang jelas, sedikit mengkilap, serta hasil yang lembut. Berikut hasil akhir cetak digital :
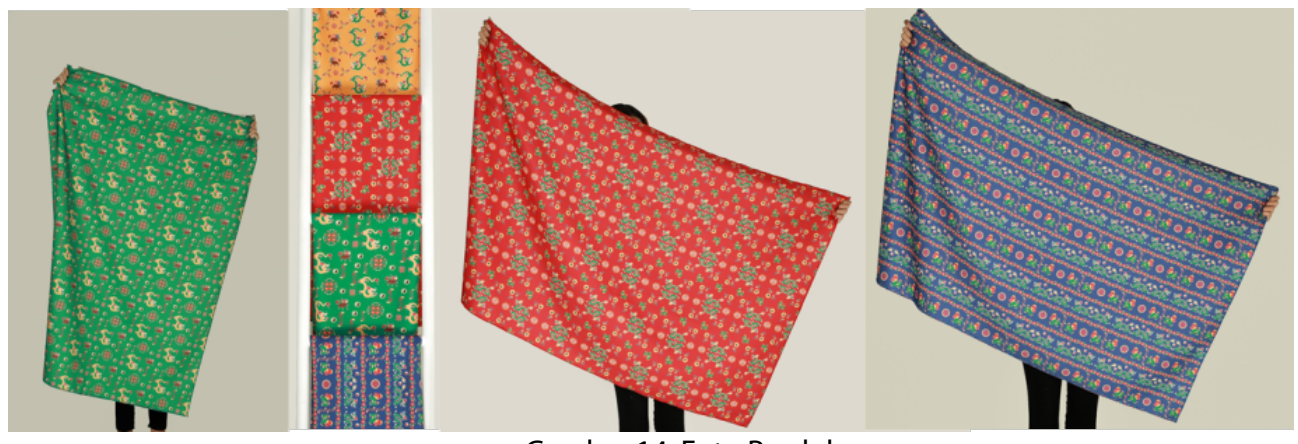

Gambar 14. Foto Produk

Sumber : Penulis, 2020

Setelah kain di cetak digital, lalu diproses dengan pola gendongan mei tai, komposisi disesuaikan dengan prinsip estetika keseimbangan dan keselarasan, dengan menggabungkan kain polos dengan kain motif. Berikut adalah hasil produk gendongan mei tai dengan motif inovasi liong: 

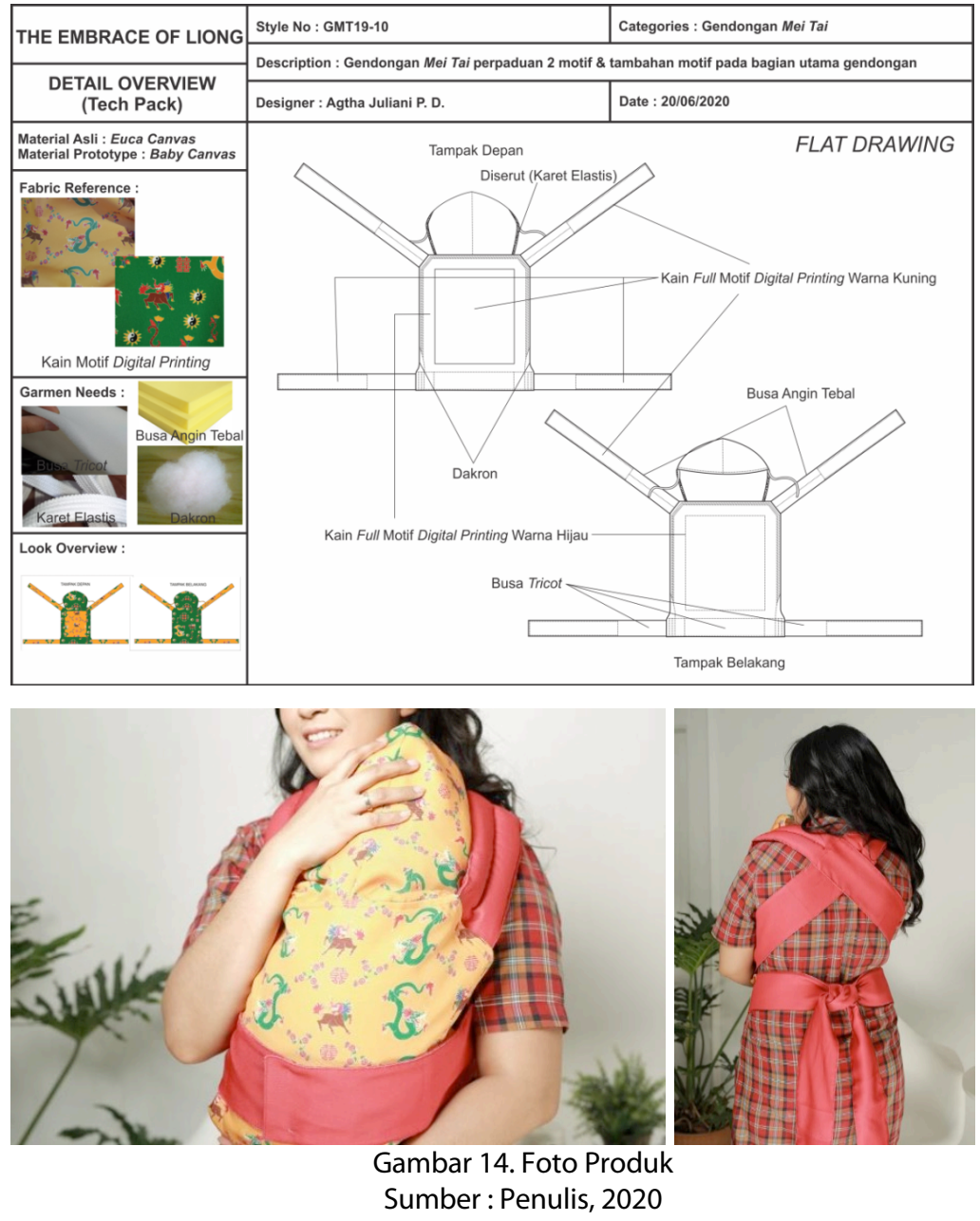

\section{Merchandise}

Merchandise berupa hang tag, business card, greeting card dan packaging. Merchandise ini dapat membantu mengenalkan kembali kain gendongan tradisional yang mulai ditinggalkan khususnya kain gendongan batik liong melalui visual.

Konsep yang diusung adalah sustain and eco-friendly, dimana packagingnya dapat digunakan secara terus menerus sehingga tidak menghasilkan limbah dan merchandise lainnya yang berupa hang tag dan greeting card terbuat dari kertas ramah lingkungan sehingga bila tidak digunakan dan dibuang akan cepat terurai. 

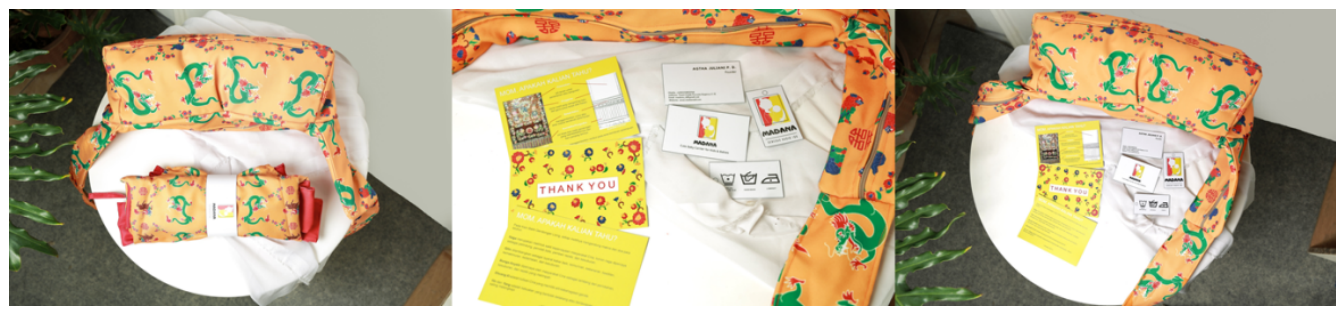

Gambar 15. Foto Merchandise Sumber : Penulis, 2020

\section{PENUTUP}

Berdasarkan hasil penelitian yang telah dipaparkan pada bab sebelumnya, maka dapat ditarik kesimpulan sebagai berikut:

1. Kain gendongan tradisional yang mulai ditinggalkan khususnya kain gendongan batik liong dapat dikenalkan kembali ke masyarakat sehingga lebih mengenal kain batik gendongan liong dengan mengambil inspirasi motif kain batik gendongan liong yang kemudian motifnya distilasi untuk membuat motif baru tanpa meninggalkan bentuk asli motifnya. Hal ini dilakukan dikarenakan adanya potensi dan motifnya yang sarat akan makna atau filosofi pada motif-motif kain batik gendongan liong, sehingga tetap mempertahankan citra dari motif kain batik gendongan liong khususnya motif-motifnya yang sarat akan makna dan filosofi pada produk gendongan modern mei tai. Selanjutnya pengenalan dilakukan dengan visualisasi merchandise, dimana desainnya dapat menarik konsumen dan adanya informasi sedikit pada merchandise. Merchandise yang digunakan adalah greeting card. Greeting card terdiri dari 2 kartu, yang pertama kartu ucapan terima kasih dan yang kedua inilah yang berisi informasi. Informasi dirangkum menjadi singkat namun customer yang membaca mudah memahami dan menambah wawasan. Informasi yang diberikan adalah struktur gendongan batik liong pada bagian depan kartu dan pada bagian belakang kartu berisi informasi tentang motif dan maknanya pada gendongan liong.

2. Terciptanya motif yang terinspirasi dari kain batik gendongan liong dengan komposisi dan bentuk yang lebih modern dapat diwujudkan dengan melakukan stilasi dan pengkomposisian motif menggunakan teknik yang lebih modern, yaitu dengan menggunakan perangkat lunak atau software Corel Draw X7. Lalu dalam pembuatan motif atau stilasi mempertimbangkan unsur dan prinsip rupa yang digunakan, yang seringkali pada kain batik gendongan liong tidak terlalu memikirkan unsur dan prinsip rupa. Dalam pengkomposisian motifpun diterapkannya teori 
repetisi seperti square repeat, half drop repeat, dan brick repeat, dan menerapkan teori orientasi motif seperti one way, two way, dan four way sehingga hasilnya lebih rapi dan terkesan modern, dimana pada kain batik gendongan liong yang asli hanya menerapkan pengulangan cermin atau mirror repeat. Ciri khas atau karakter kain batik yang memiliki outline putih seperti penggunaan lilin batik dan warna yang cenderung offside atau meluber (keluar bidang) dapat dikejar atau diperoleh dengan menggunakan perangkat lunak atau software Corel Draw X7 juga.

3. Terciptanya produk gendongan mei tai yang menerapkan rancangan pengolahan motif yang terinspirasi dari kain batik liong yang lebih modern dan memiliki unsur budaya dapat diwujudkan terbukti dengan hasil produk dari penelitian ini. Olahan motif yang sudah distilasi dengan menggunakan perangkat lunak atau software Corel Draw X7 serta diterapkan teori repetisi dan orientasi motif yang sudah diasistensi atau terpilih dicetak pada kain baby canvas. Kain bermotif tersebut sudah mengandung unsur budaya karena melalui pengolahan motif yang terinspirasi dari motif kain batik gendongan liong, yang kemudian melalui tahap produksi pembuatan gendongan anak modern jenis mei tai. Berdasarkan sketsa perancangan produk, kain bermotif ini dapat diterapkan pada seluruh bagian gendongan anak mei tai seperti bagian utama, tali panel bahu dan pinggang, hoodie, dll. Pada sketsa perancangan yang direalisasikan menjadi produk menunjukkan olahan motif yang terinspirasi dari motif kain batik gendongan liongdapat diterapkan atau digunakan pada bagian utama gendongan anak mei tai dan hoodie, sedangkan pada tali panel bahu dan pinggang dibuat polos dengan tujuan tidak monoton.

\section{DAFTAR PUSTAKA}

Holmes, G. S. (2019). Baby Carrier. https://www.encyclopedia.com/manufacturing/news-wireswhite-papers-andbooks/baby-carrier.

Hout, I. C. Van. (2015). Beloved Burden: Baby Wearing Around the World. LM Publishers.

Ishwara, H. dkk. (2011). Batik pesisir Pusaka Indonesia: Koleksi Hartono Sumarsono. . Kepustakaan Populer Gramedia.

Ismawati. (2019). Cara Memilih Gendongan Bayi yang Tepat. https://www.ibupedia.com/artikel/balita/13-cara-memilih-gendongan-bayi-yangtepat.

Kight, K. (2011). A Field Guide to Fabric Design. Stash Books.

Kudiya, K. (2019). Kreativitas dalam Desain Batik, Bandung: Penerbit ITB Press. ITB Press. 
McCarthy, L. (2007). Meh Dais: What They Are and Why You Want One.

Rosandini, M., \& Kireina, Y. (2020). Kajian Bahasa Rupa pada Batik Gendongan Lasem Motif Pohon Hayat dan Satwa. Gelar: Jurnal Seni Budaya, 18(1), 16-22.

Tabrani, P. (2005). Bahasa Rupa. Kelir.

Tjandrawibawa, P. (2018). Motif Tekstil Sebagai Value Proposition Koleksi Brand Fesyen Yang Marketable. Serat Rupa Journal of Design, 2(1), 26. https://doi.org/10.28932/srjd.v2i1.475

Vintage Mei tai /Meh Dai Part 1. (2018). https://www.hipababy.com.au/blog/vintage-mei-taimehdai-part-1.

Wulandari, A. (2011). Batik Nusantara: Makna Filosofis, Cara Pembuatan dan Industri Batik. Penerbit Andi.

\section{Wawancara}

Mu'minah, Afifah. (2019). Certified Babywearing Consultant, pada Oktober 2019, Bandung. 